\title{
Lessons from Shakespeare's tiger mothers: parental and political authority in Coriolanus and Merchant of Venice
}

\author{
ANNALISE ACORN \\ Professor of Law
}

and

Katherine Clackson

Royal \& Co Barristers and Solicitors

\section{Introduction: Amy Chua and William Shakespeare}

Y ale Law Professor Amy Chua's memoire Battle Hymn of the Tiger Mother ${ }^{1}$ created a media sensation. ${ }^{2}$ The book struck a powerful chord as hundreds clamoured to register either horror or approval of Chua's confessing to and advocating for a model of mothering that mixes in equal measure asceticism, relentless demands for public achievement, and love (albeit conditional). Many saw Chua's tract as little more than a self-serving apology for child abuse. Others viewed her sometimes astonishingly honest exposé as a refreshing antidote to the cult of self-esteem that predominates the theory and practice of childrearing at the beginning of the twenty-first century. ${ }^{3}$

But for both the outraged and the inspired, the reason Chua's book resonated so deeply was that it raised, with high drama, timeless questions about the limits and legitimacy of parental authority and the value of children's obedience over self-assertion and rebellion. In

Amy Chua, Battle Hymn of the Tiger Mother (Penguin 2011).

2 See e.g. Janet Maslin, 'But Will It All Make “Tiger Mom” Happy?’ New York Times (New York, 19 January 2011) <www.nytimes.com/2011/01/20/books/20book.html?_r=2>; Kate Zernike, 'Retreat of the "Tiger Mother" New York Times (New York, 14 January 2011) <www.nytimes.com/2011/01/16/fashion/ 16Cultural.html?ref=books>; Judith Warner, 'No More Mrs. Nice Mom’ New York. Times (New York, 11 January 2011) <www.nytimes.com/2011/01/16/magazine/16fob-wwln-t.html?ref=books>; Sheryl Sandberg, 'Tough-Love Mother' Time Magazine (New York, 21 April 2011) <www.time.com/ time/specials/packages/article/0,28804,2066367_2066369_2066449,00.html>; Joanne Moorhead, 'The Tiger Children Fight Back Against Amy Chua' The Guardian (London, 9 December 2011) <www.guardian.co.uk/ commentisfree/2011/dec/09/tiger-children-fight-back>; Anne Kingston, 'Amy Chua on High-stakes Parenting' Maclean's (Toronto, 13 January 2011) <www2.macleans.ca/2011/01/13/amy-chua-on-high-stakesparenting/>; Rebecca Dube, 'The "Tiger Mothers and Harsh Parenting', MSNBC (10 January 2011) <http://moms.today.msnbc.msn.com/_news/2011/01/10/5806202-the-tiger-mother-and-harshparenting>; Elizabeth Kolbert, 'America's Top Parent: What's behind the “Tiger Mother" Craze?' New Yorker (New York, 31 January 2011) <www.newyorker.com/arts/critics/books/2011/01/31/ 110131crbo_books_kolbert>; 'The Tiger Mother Responds to Readers' Wall Street Journal (New York, 13 January 2011) <http://blogs.wsj.com/ideas-market/2011/01/13/the-tiger-mother-responds-to-readers/>; Kevin Dolak, 'Strict, Controversial Parenting Style Leads to Death Threats for "Tiger Mother" Amy Chua' ABC News (17 January 2011) < http://abcnews.go.com/US/tiger-mother-amy-chua-death-threats-parentingessay/story?id=12628830\#. Twst5BxE4zA>.

3 For an analysis of the cult of self-esteem see Lori Gottlieb, 'How to Land Your Kid in Therapy' (2011) (July/August) Atlantic Magazine <www.theatlantic.com/magazine/archive/2011/07/how-to-land-your-kid-intherapy/8555/\#.T0liS1nz7mc.mailto>. 
a society addicted to freedom, or at least to choice, Chua's unabashed arrogation of absolute power and limitless authority over her children read as tyrannical and prompted searching questions about when parents can legitimately claim to know best and to demand unquestioning obedience from their children. Yet, in a society also addicted to celebrity, Chua's success in propelling her daughter Sophia to Carnegie Hall read as enviable and prompted equally searching questions about when hard treatment of a child can be justified by the hope of future glory.

Though Chua credits Chinese culture and the legacy of her own Chinese immigrant parents with the inspiration and model for tiger-mothering, she sees the archetype of the Chinese mother as having application far beyond the Chinese-American community. ${ }^{4}$ Chua promotes the role as being available to men and women of all ethnicities. A Chinese mother may be 'Korean, Indian, Jamaican, Irish [or] Ghanaian'. ${ }^{5}$

Though she draws the portrait of the Chinese mother as inclusive across gender and ethnicity, what Chua is slower to acknowledge is the timeless nature of the trope of pushy parent who uses a combination of tough love, deprivation and demand to raise super-kids. Had she looked to literature, Chua would have found some instructive portrayals of such parents. Moreover, literature would have been a valuable source for gaining insight into some of the distortions and pathologies to which such childrearing tactics have long been subject.

Shakespeare, as always, is a goldmine. In many of his portrayals of the parent-child relationship Shakespeare explores the extent of the parent's legitimate authority over the child as well as the legitimacy of parents' attempts to control and mould their children in the service of family ambition. What one finds in Shakespeare is, for the most part, a catalogue of failures of tiger-mothering. In many of his portrayals of the parent who is ambitious for his or her child's success, Shakespeare focuses on the various pathologies to which such a parent-child relation is subject.

Old Hamlet, for example, can be read as a failed tiger mother. ${ }^{6}$ He demands that young Hamlet achieve as an avenger and attempts to substitute his own agenda of payback for Hamlet's authentic desires and inclinations. King Lear is likewise unsuccessful in his attempts to exert controlling authority over his daughters and to command their love and care for him in his old age. ${ }^{7}$ Constance of King John is relentless in her ambition to have her son Arthur crowned king, and her single-minded push for his coronation puts in motion events that lead to his death. ${ }^{8}$

Perhaps Henry IV comes closest to being a successful tiger mother to Prince Hal even though he fails at first in his struggles to dominate Hal's wild spirit and to direct him towards the ambitions of excellence that he cherishes for him. ${ }^{9}$ A typical tiger mother, Henry IV tries in myriad ways to manipulate Hal into obedience. He is consumed with envy over Henry Percy's success in raising the young Hotspur, and holds up Hotspur as the son he wishes he had in order to shame prince Hal. But Hal is all rebellion - at least until it really counts. In the end it is perhaps despite Henry IV's tiger-mothering rather than because of it that Hal comes into his own, on his own, as Henry V, a greater king by far than was his father.

4 Chua (n 1$) 4$.

5 Ibid.

6 William Shakespeare, Hamlet (OUP 2009).

7 William Shakespeare, King Lear (Penguin 1998).

8 William Shakespeare, King John (OUP 1989) (Queen Elinor: 'have I not ever said/ How that ambitious Constance would not cease/ Till she had kindled France and all the world,/ Upon the right and party of her son?’ (I.i.31-34).

9 William Shakespeare, Henry IV, Part I (OUP 2008). 
Though these are all fascinating explorations of parental authority and vicarious ambition, we have chosen here to focus on two contrasting portrayals of the parent-child relationship. First, we will examine the relationship between Volumnia and her son Coriolanus in Coriolanus, one of Shakespeare's lesser-known tragedies recently brought to renewed attention with Ralph Fiennes' powerful film version; ${ }^{10}$ and that between Shylock and his daughter Jessica in, what is perhaps an equally tragic play, The Merchant of Venice. ${ }^{11}$ Coriolanus and The Merchant of Venice depict distinct, and indeed polarised, failures of the tiger-mother model. With Coriolanus the model fails because his tortured internalisation of his mother's command overbears his independent judgment and sense of self to his own disastrous ruin. With Jessica the model also fails but in the opposite way. Jessica's refusal to internalise her father's aspirations for her, her total rejection of his outsider vision of her future and her worth lead her to 'go public' with her rebellion in a way that leads to the disastrous ruin of Shylock himself. ${ }^{12}$

\section{2 'Thy valiantness was mine': Volumnia and Coriolanus}

In the opening lines of Shakespeare's Coriolanus we learn that Caius Marcius (later Coriolanus) is a superhuman warrior, that he is proud, disdains the people, and that they in turn suspect that love of country is not what has motivated his triumphs:

First citizen:

I say unto you, what he hath done famously, he did it to that end: though soft-conscienced men can be content to say it was for his country he did it to please his mother and to be partly proud; which he is, even till the altitude of his virtue. ${ }^{13}$

We are thus aware even before we meet Coriolanus that he is in the thrall of a tiger mother. The ensuing scenes reveal a textbook relationship between seemingly successful tiger mother and her ultra-accomplished child. He holds himself to superhuman standards of excellence and she is the push and motivation behind his success.

\section{(A) VOLUMNIA AS TIGER MOTHER}

In what follows we will describe core aspects of the tiger-mother model as Chua articulates it and show both how Volumnia typifies those attributes in her relationship with Coriolanus and how the model is subject to degeneration and distortion as Coriolanus is destroyed by his inability to break free from his mother's control.

10 Director Ralph Fiennes sets the play in the Balkans in the 1990s. He plays the title role, with a spectacular performance also given by Vanessa Redgrave as Volumnia. See Anthony Lane, 'Ralph Fiennes' Coriolanus, Review' New Yorker (New York, 23 January 2012); Peter Bradshaw, 'Coriolanus Review' The Guardian (London, 19 January 2012.

11 William Shakespeare, Coriolanus (OUP 2008); William Shakespeare, The Merchant of Venice (OUP 1993). See William Ian Miller, Eye for an Eye (CUP 2006). Miller states that The Merchant of Venice invokes in him emotions that are closer to those he feels when reading King Lear than a comedy (71). See also Madelon Sprengnether, 'Annihilating Intimacy in Coriolanus' in David Wheeler (ed), Coriolanus: Critical Essays (Garland 1995), in which the author discusses the threat that Volumnia poses to Coriolanus' identity, and that this is a condition that he 'both desires and fears' (188).

12 See Chua (n 1) 172 where she discusses the crisis that ensued when her younger daughter Lulu 'went public' with her rebellion.

13 Coriolanus (n 11) I.i.33-7, 160. 


\section{(i) No pain, no gain}

As a tiger mother, Volumnia takes pride, and even pleasure, in the pain and suffering her son endures to achieve military victories for Rome. Volumnia articulates her cheerful attitude toward the prospect of her son's being injured in battle as she reproaches her daughter-in-law who fears for Coriolanus' safety:

Away, you fool! [blood] more becomes a man

Than gilt his trophy: the breasts of Hecuba,

When she did suckle Hector, look'd not lovelier

Than Hector's forehead when it spit forth blood

At Grecian sword, contemning. ${ }^{14}$

Volumnia thrills with pride when she learns that her son has been victorious against the Volsces and has singlehandedly taken the city of Corioli. But she delights even more in the news of her son's wounds and conceives of them as stepping-stones to further public glory.

$\mathrm{O}$, he is wounded; I thank the gods for't. ${ }^{15}$

And in answer to the question of where her son has been wounded, Volumnia, mindful of the instrumental value of the wounds in promoting his career, enthusiastically replies:

I' the shoulder and i' the left arm there will be

large cicatrices to show the people, when he shall

stand for his place. ${ }^{16}$

Of course, few tiger mothers (at least few in present day North America) can match Volumnia's exaggerated pose here, casting the very body and even life of her son as purely instrumental to achievement. But the perverse pleasure in the child's suffering is clearly in evidence in Chua's self-description. For example, Chua tells of discovering her daughter Sophia's teeth marks on the keys of their piano. The image of the child silently struggling against the demand to practise beyond her own endurance, the teeth marks as evidence of an inward-turning rebellion of a child pushed past her capacity elicits powerful pathos in the reader. Yet Chua's reaction holds fast to a vicarious ethic of 'no pain, no gain' for her daughter. Chua seems to see the teeth marks as badges of honour, as battle scars that are instrumental to her daughter's further achievement. ${ }^{17}$

For Chua, as for Volumnia, equanimity about the child's suffering is justified on 'whatever does not kill [them] makes [them] stronger' reasoning. ${ }^{18}$ Chua insists that the tiger-mother model in its extreme demands on the child signals to the child confidence in the child's strength. She writes: 'Western parents are concerned about their children's psyches. Chinese parents aren't. They assume strength not fragility, and as a result they behave differently. ${ }^{19}$ Likewise, Volumnia sees her presumption of invincibility as empowering for her son. By sending him into danger as a young child she signals to her son early on her belief that he is capable of triumphing over extreme adversity.

14 Coriolanus (n 11) I.iii.40-4, 180-1.

15 Ibid II.i.118, 212.

16 Ibid II.i.143-45, 213.

17 See Chua (n 11) 58-59. Chua is enigmatic in her discussion of the teeth marks. She seems to suggest that she knows that Sophia is not really enjoying playing the piano because she tells the story of the teeth marks in response to a comment that Sophia seems to enjoy playing piano.

18 Friedrich Nietzsche, Twilight of the Idols, Duncan Large (trans) (OUP 1998) 8th maxim.

19 Chua (n 1) 52. 


\section{(ii) Insatiability}

Another textbook trait of the tiger mother that Chua and Volumnia share is the unwillingness or perhaps even the inability to be satisfied with any of their children's achievements. Nothing is ever enough. Each success, though imperative prior to its attainment, is discounted as soon as it is won and upon attainment is immediately reread as a call to higher glory. Chua's pride at Sophia's playing the piano in Carnegie Hall at the age of 14 is soon succeeded by the observation that her daughter only played in the smaller venue. Chua writes: 'I couldn't help notice that the Weill Recital Hall, where Sophia played - while quite charming with its belle époque arches and symmetrical proportions - was a relatively small venue, located on the third floor of Carnegie Hall. ${ }^{20}$ Of course, Chua sets her sights on the main hall for her daughter. Likewise, her younger daughter Lulu's success in impressing her famous violin teacher is discounted immediately and serves only as pressure for her to perform better the next day and as a demand that she continue to practise even after a full day of playing the violin. ${ }^{21}$

Volumnia's joy at her son's victorious return from battle with the Volsces, his being renamed Coriolanus in recognition of his having taken the city of Corioli singlehandedly, even his numerous wounds 'each marking the grave of an enemy' is only momentary and is very soon displaced by the demand that he become consul of Rome. Volumnia says:

I have lived

To see inherited my very wishes

And the buildings of my fancy: only

There's one thing wanting, which I doubt not but

Our Rome will cast upon thee. ${ }^{22}$

That line: 'Only there's one thing wanting' epitomises the tiger mother. For her, there is always more that can be done. And Shakespeare masterfully shows how that maternal insatiability creates the most potentially destructive tensions between the tiger mother and her super-kid. It is here that Coriolanus first attempts to assert his will in opposition to Volumnia as he replies:

Know, good mother,

I had rather be their servant in my way,

Than sway with them in theirs. 23

Throughout the play the people's tribunes warn of the threat that Coriolanus poses to the democratic rights of the people. They suspect that if he gains the consulship he will trample the people's rights and set himself up as a tyrant. For the most part, we dismiss the argument as mere political opportunism on the part of the tribunes. Coriolanus does not even want to be consul let alone a tyrant. But what about his mother? The insatiability of Volumnia's ambition for her son combined with Coriolanus' compulsion to satisfy her demands makes the tribunes' cautions about tyranny more credible.

\section{(iii) Mother knows best}

Coriolanus' understanding of his self-interest is continually pitted against his mother's judgment about what is best for him. As a true tiger mother Volumnia believes that she has

20 Chua (n 1) 140-41.

21 Ibid 143.

22 Coriolanus (n 11) II.i.194-98, 217.

23 Ibid II.i.198-99, 217. 
exclusive access to decisions about what is good for her son. As Chua puts it: 'Chinese parents believe they know what is best for their children and therefore override all of their children's own desires and preferences.' 24 Against his own wishes to remain a purely military man, Coriolanus accedes to his mother's desire that he become consul. The senate readily agrees to his appointment, but the people must ratify the decision. The ancient custom is for the candidate to put on the 'gown of humility', show his wounds and ask for the people's 'voices'. ${ }^{25}$ But Coriolanus, half-hearted in his desire for the position and imbued with his mother's elitism and contempt for the common people, is stiff and insolent in his campaign. Though they initially vote to confirm his office, soon the people renege on their decision and withdraw their confirmation.

Volumnia's supreme confidence in her own superior understanding of Coriolanus' best interests is reiterated as she continues to push him to secure the position of consul even as the politics of attaining it become more intractable. The people's hostility to Coriolanus escalates and some begin to call for his execution. Volumnia demands that he return again to humble himself to the people and win their support. ${ }^{26} \mathrm{He}$ is shocked that his mother would want him to pander to the masses. But Volumnia wants the consulship and far from approving of her son's stubborn adherence to their shared elitist principles she denounces him for his failure of political strategy. She says:

You might have been enough the man you are,

With striving less to be so; lesser had been

The thwartings of your dispositions, if

You had not show'd them how ye were disposed

Ere they lack'd power to cross you. ${ }^{27}$

Coriolanus is stunned by the betrayal. But for Volumnia the game of ridiculing the lower classes stops when winning their support is necessary for advancement. Coriolanus is very aware of the threat that obeying or giving in to his mother poses to his best interests as he sees them. He says:

I will not do't,

Lest I surcease to honour mine own truth

And by my body's action teach my mind

A most inherent baseness. ${ }^{28}$

In Volumnia's response: 'At thy choice, then' she dares her son to defy her and in so doing secures his obedience. ${ }^{29}$ She wagers that his statement 'I will not do' $t$ ' is an attempt to persuade her to accept his understanding of his best interests and to endow his independent choices with the force of her authority. But Volumnia does not believe either that he is right or even that his estimation of his best interests matters. Like Chua, she feels justified in

24 Chua (n 1) 53.

25 Coriolanus (n 11) II.iii.151, 239.

26 A moment of tremendous pathos comes when Coriolanus is confused by the disharmony between his mother's desires and his own. He says: 'I muse my mother/ Does not approve me further, who was wont/ To call them woollen vassals, things created/ To buy and sell with groats' (III.ii.7-10, 266). Coriolanus understands the relation between himself and his mother as one of absolute loyalty bound by shared commitment to superiority. Their mutual disdain for the plebeians is a source of their love for each other. Sharing in contempt for the common people is what Coriolanus and his mother do most happily together. Coriolanus (n 11) III.ii.19-23, 267.

28 Ibid III.ii.122-24, 274.

29 Ibid III.ii.125, 274. 
overriding all her child's preferences. She is supremely confident that seeking what is best for him does not entail respecting or supporting his autonomy. Because Volumnia is sure that she is right, nothing matters more than securing her son's obedience. His autonomy, his right to be wrong or his right simply to decide on his own has no independent value for her.

Volumnia pushing Coriolanus to win the favour of the people is, in an exaggerated way, similar to Chua pushing her daughter Lulu to play 'Hebrew Melody' on the violin at Lulu's Bat Mitzvah. Coriolanus and Lulu's reasons for not wanting to do the thing make more sense than their mothers' reasons for wanting them to. In both cases the mother is blindly relentless against all reason and prevails. For Chua the victory seems to validate the madness of her insistence. Chua's sense of triumph is made possible because Lulu pulls off the performance in the end. Coriolanus, by contrast, submits to Volumnia's will but fails in his performance. Volumnia blames her son and not herself for the failure. But both mothers skirt the question of whether it was right to stop at nothing to impose their version of the good on their child.

\section{(iv) Guilty indebtedness}

Volumnia does not rest her claim to authority solely on this sense of superior knowing. She goes on to buttress this argument for her authority with an argument of indebtedness. Again we see the same sentiment articulated by Chua: 'Chinese parents believe that their kids owe them everything ... Chinese children must spend their lives repaying their parents by obeying them and making them proud. ${ }^{30}$ Condemning Coriolanus' stubbornness and unwillingness to play to the masses to gain power, Volumnia shames her son, saying:

Thy valiantness was mine, thou suck'dst it from me. ${ }^{31}$

Here we see inexpiable indebtedness as a further argument for the mother's absolute authority over the child. The child acquires good qualities by consuming the mother's. Yet, rather than divesting the mother of her own strength, the transfer allows her to retain control over the child. Evoking the image of the breast, Volumnia claims credit for and property in her son's achievements by virtue of her having transfused her own strength and courage to him. She feeds him and in turn has her desires fed by the glory that his actions produce. Volumnia sustains the rhetoric of reciprocity throughout the play, relentlessly grounding her claim to authority over him in the logic of debt.

Coriolanus, internalising this view of his indebtedness to his mother, relents again agreeing to return to the people against his own desire. ${ }^{32}$

Pray, be content:

Mother, I am going to the market-place;

Chide me no more. 33

\section{(v) Vicariousness}

A final attribute of the tiger mother that Chua and Volumnia share is that they live vicariously through their children. They consume their children's accomplishments and crave glory for their children as glory for themselves. This aspect of tiger-mothering is one that Chua vehemently denies. She writes:

30 Chua (n 1) 53.

31 Coriolanus (n 11) III.ii.131, 274.

32 Early on in the play we see that Coriolanus credits his mother with his accomplishments, further reflecting his sense of indebtedness to her. When he returns from victory over the Volsces he says to her: 'O, You have, I know, petition'd all the gods For my prosperity!' and kneels to his mother (II.i.165-167, 215).

33 Coriolanus (n 11) III.ii.132-34, 274. 
Here's a question I often get: 'But Amy, let me ask you this. Who are you doing all this pushing for - your daughters' - and here always the cocked head, the knowing tone - 'or yourself?' I find this a very Western question to ask (because in Chinese thinking, the child is the extension of the self). But that doesn't mean it's not an important one.

My answer, I'm pretty sure, is that everything I do is unequivocally $100 \%$ for my daughters. My main evidence is that so much of what I do with Sophia and Lulu is miserable, exhausting and not remotely fun for me. ${ }^{34}$

Chua's claim that her own misery in pushing her children proves her selflessness is obviously flawed. That a tiger mother is willing to endure hardship to make her child perform is no proof that the performance is not primarily for the mother. Indeed, the logic contradicts one of Chua's implicit principles - that nothing is enjoyable unless it is difficult.

Volumnia's desire to live through her son is evident throughout Coriolanus. Shakespeare points to our anxiety around this vicariousness in a speech by the patrician Menenius. After the people have overturned Coriolanus' election and the tribunes are calling for his death, Menenius tries to reason with the people on Coriolanus' behalf arguing:

Now the good gods forbid

That our renowned Rome, whose gratitude

Towards her deserved children is enroll'd

In Jove's own book, like an unnatural dam

Should now eat up her own! ${ }^{35}$

Menenius' argument is persuasive against the tribune's impulse to strike down Coriolanus. But the image of the mother devouring her deserving child resonates less with our anxiety about Coriolanus' figurative mother Rome than with his real mother Volumnia's propensity to consume him. The mother sacrifices her child on the altar of her own vicarious pleasure. The play depicts the extremes of vicariousness in the parent-child relationship. Volumnia lives off and through Coriolanus' accomplishments and our anxiety about her manipulating him to feed her own ambition and desire is heightened by the imagery of cannibalism in the play. ${ }^{36}$

\section{(B) Volumnia's fallure AND CoriOlanus' RuIN: DEMOCRACY AND SElF-RUle}

In Coriolanus, Shakespeare depicts one pathological outcome of the tiger-mother model. What we see most graphically in the play is the tiger mother producing an adult child who is incapable of self-rule. Coriolanus has internalised his mother's authority over him. He believes himself to be guiltily indebted to her not just for life, but for the impetus to all his achievements.

The relation between Coriolanus and his mother can be understood in terms of Ronald Dworkin's distinction between personal preferences (desires one has for oneself for what one wants to have and do) and external preferences (desires one has about what others should have and do). ${ }^{37}$ Coriolanus' deliberations for his own action are dominated by his mother's external preferences (her desires for what he should do). Her aspirations for him

34 Chua (n 1) 148.

35 Coriolanus (n 11) III.i.292-96, 263.

36 Later, after Coriolanus is banished, Volumnia refuses Meninius' invitation to dinner stating: 'Anger's my meat; I sup upon myself/ And so shall starve with feeding' (IV.ii.53-54, 291). With her usual narcissism, Volumnia casts herself as both the eater and eaten. Yet, it is Coriolanus not Volumnia who appears now fallen in stature, emaciated as he has renounced more and more of himself and abdicated self-command over to his mother's ends.

37 Ronald Dworkin, Taking Rights Seriously (Duckworth 1987) 234. See also Brian Barry, Political Argument (Routledge \& Kegan Paul Ltd 1965) for a distinction between 'privately and publically oriented judgements and wants' (12-13). 
trump his own desires. He cannot value his own personal preferences (his own estimation of what he should have and do) with the same commitment as he values her external preferences for him. This valuation of her desires over his own is what compels Coriolanus always to continue to extend his consent to her authority over him.

After Coriolanus is banished by the people for yet another failed attempt to gain their favour, he leaves the city and joins with his former arch-enemy the general of the Volsces, Tullus Aufidius. ${ }^{38}$ The two plan an attack on Rome together. But when they arrive to carry out their plan, Coriolanus again faces his mother. It is here that Volumnia's manipulation of her son reaches its highest pitch. She begins by reminding him of what he knows has always been her greatest desire - that he should be extolled in reputation in Rome. Volumnia has always seen her son's life as at bottom only instrumental to his 'good report' and he knows it. ${ }^{39}$ Thus he is weakened in his resolve by her argument:

if thou conquer Rome, the benefit

Which thou shalt thereby reap is such a name,

Whose repetition will be dogg'd with curses 40

Further, in trying to persuade him not to go against Rome she kneels to him:

with no softer cushion than the flint,

I kneel before thee; and unproperly

Show duty, as mistaken all this while

Between the child and parent. ${ }^{41}$

She shames him by humbling herself to him making him feel the unnatural reversal of the hierarchy between mother and child. She trusts that his discomfort at seeing her humiliated before him will be intolerable to him; that he will be compelled to end her debasement by acceding to her demands. The tactic is dependent upon his internalisation of her claim that he is bound to elevate and obey her. She strikes a posture of self-humiliation only as another means of dominating him. ${ }^{42}$

The play's most obvious themes are about the competing claims of democracy and aristocracy as systems of government. As William Hazlitt wrote:

Any one who studies [Coriolanus] may save himself the trouble of reading Burke's

Reflections, or Paine's Rights of Man, or the Debates in both Houses of Parliament since the French Revolution or our own. The arguments for and against aristocracy or democracy, on the privileges of the few and the claims of the many, on liberty and slavery, power and the abuse of it, peace and war, are here very ably handled, with the spirit of a poet and the acuteness of a philosopher. ${ }^{43}$

Hazlitt concludes, however, that Shakespeare tentatively comes down on the side of arbitrary power engaging us in the poetic majesty of Coriolanus' solitary power. Yet, read from the vantage point of the relationship between Volumnia and Coriolanus, the play's

38 Coriolanus (n 11) IV.v.66-102, 299-301.

39 When Virgilia recoils at Volumnia's enthusiasm at sending her son into the dangers of war and asks: 'But had he died in the business, madam; how then?' Volumnia replies: 'Then his good report should have been my son, I therein would have found issue' (I.iii.19-21, 179).

40 Coriolanus (n 11) V.iii.143-45, 340-41.

41 Ibid V.iii.53-56, 335.

42 Volumnia's use of self-abnegation as the ultimate means of extracting obedience from her son comes when she threatens suicide unless he turns back from his campaign against Rome.

43 William Hazlitt, A View of the English Stage: Dramatic Essays (Anderson and Chase 1818) 124. 
ideas about the relation between democracy and aristocracy are more complex. The relation between Volumnia and Coriolanus raises the question of how authority structures within the family are replicated in the political sphere. Hazlitt sees Coriolanus as the beacon of aristocracy in the play, such that when we favour Coriolanus over the plebeians we favour aristocracy. However, looked at from another angle, Coriolanus himself demonstrates that those who are habituated to authoritarian control are unable to break free from domination and effectively exercise the kind of responsible free will necessary to a functioning democracy. Thus, within the character of Coriolanus we see a mirror of the critique of democracy contained in the play.

In so far as the play is critical of democracy, it is the fickleness of the people, their propensity to change their minds and their vulnerability to being manipulated by others that mars democratic rule and makes it seem short-sighted and ineffective. When Coriolanus discovers that the people have reneged on their earlier decision to elect him consul he storms: 'Have I had children's voices?'44 Later we see a caricature of the people as children fluctuating between opposite political opinions depending on the immediate stimulus. When they hear that Coriolanus is returning from exile to go against Rome they attempt to disclaim responsibility for their actions: 'though we willingly consented to his banishment, yet it was against our will'. ${ }^{45}$ The line suggests a lack of comprehension of the very idea of consent and seems to denote an oxymoron. Consent, as an expression of the will, cannot be against the will.

However, though the line elicits contempt for the plebeians its seemingly empty conceptual distinction actually describes perfectly the failure of autonomy to which Coriolanus himself is subject. At every turn he consents to his mother's authority over him, yet the course of action he chooses as a result of her manipulation is never in harmony with his independent intentions. He is manipulated by her demands and aspirations to forsake his own desires and substitute her wishes for his independent agency. He consents, yet it is against his will.

The play shows that, like the plebeians, Coriolanus is not capable of self-government. He can't validate his own internal preferences as reasons for action. He does not know himself well enough to be able to formulate and act on his own evaluation of his situation. He is not capable of projecting his will into the future because he does not know when he will be undercut by his mother's desires. Shakespeare's ideas about the tension between democracy and aristocracy perhaps go beyond even the considerable sophistication that Hazlitt attributed to him in understanding the nuances of the relative merits of democracy and aristocracy. Coriolanus comments on the even more complex issue of the perils of transition from aristocracy to democracy in a society where people are unaccustomed to self-rule. ${ }^{46}$

Throughout Chua's book, she expresses scepticism about the value of democracy and autonomy. Indeed, Chua often describes such values as aspects of Western culture that stand in the way of the success of the Chinese model of parenting. Chua reveals on a number of occasions her sense that the antidemocratic and authoritarian values of Chinese culture better support the practice of tiger-mothering. While Chua has equanimity about the damaging effect the tiger-mother model can have on democratic values and the development of the capacity for self-rule, Shakespeare depicts that possibility as deeply troubling.

44 Coriolanus (n 11) III.i.32, 247.

45 Ibid IV.vi.153, 316.

46 See Amy Chua, World on Fire: How Exporting Free Market Democracy Breeds Ethnic Hatred and Global Instability (Anchor Books 2003) for the author's views on the risks of importing democracy into societies historically ruled by dictatorship. 
Coriolanus' final failure to honour his own judgment and muster the strength necessary for self-rule leads to his death. He capitulates to his mother's plea that he spare Rome. He attempts to 'frame convenient peace' between Rome and the Volsces, asking Aufidius to go along with his change of heart. Though Aufidius gives an outward show of agreement, he is planning Coriolanus' death. Contemptuously calling him a 'boy of tears', Aufidius orders his men to kill Coriolanus. ${ }^{47}$ Thus, Coriolanus dies to the echo of insult; the naming of his infantalisation and the rejection of his claim not just to the heroic, but to manhood itself.

\section{The 'fast bind, fast find' fallacy: Shylock and Jessica}

\section{(A) SHYLOCK, MinORITY PARENTS AND the PROTECTION FROM 'Western' INFLUENCE}

While Coriolanus depicts one exaggerated and pathological form of the tiger mother, The Merchant of Venice depicts an altogether different failure of the model. Shylock is a single parent whose vision of the good for his daughter is fundamentally at odds with the dominant and profoundly licentious culture that surrounds him. Like Chua, he is attempting to discipline his daughter in opposition to ubiquitous permissive influences. For Chua much of the work of Chinese mothering involves filtering out 'Western' influences and prohibiting Western pastimes that hinder her daughters' success, as well as her ability to parent them the Chinese way. Like Chua, Shylock believes that prohibiting fun with the kids next door is in the ultimate best interests of his daughter. As a Jew, Shylock is an outsider. And as a Jew he does not desire assimilation for himself or his family. He has contempt for the 'endless luxury' and indulgence of the Christians of Venice and he strives to shelter his daughter from those influences and to inculcate in her the values of pious Jewish life characterised by obedience and temperance. ${ }^{48}$

Just as Chua prohibits sleepovers, playdates, the school play, TV and computer games, so Shylock attempts to shut out the carnival atmosphere of Venice in order to protect Jessica from its immorality and decadence. On the ill-fated night that Shylock leaves Jessica alone while he goes to dinner with the Christians he says to her:

Hear you me, Jessica:

Lock up my doors; and when you hear the drum

And the vile squealing of the wry-neck'd fife,

Clamber not you up to the casements then,

Nor thrust your head into the public street

To gaze on Christian fools with varnish'd faces,

But stop my house's ears, I mean my casements:

Let not the sound of shallow foppery enter

My sober house. 49

Again, Shylock's brand of tiger-mothering focuses on deprivation. Not only does he not want Jessica to participate in the frivolity of the Christian neighbours, he does not even want her watching it through the window - perhaps the sixteenth-century equivalent of TV. But Shylock's motives are sincere and perhaps more complex than Chua's. Not only does he reject the prodigal lifestyle of the Christians as morally inferior to pious Jewish life, he also fears the threat that Christian culture poses to his daughter. He knows that he and his daughter live in a Jew-hating world and he believes that Jessica is at risk of being exploited

47 Coriolanus (n 11) V.vi.103, 355.

48 Miller (n 11) 73.

49 Merchant (n 11) II.v.28-36, 143-44. 
and hurt by unscrupulous Christian predators. Shylock is not aiming to make Jessica into a virtuoso. He just wants her to be a virtuous Jewish woman and his depriving her of entertainment and fun is aimed at trying to protect her from desiring the decadent life of the Christians and from incurring the serious risks to her well-being that he fears the Christians might pose for her. While Chua raises her daughters the Chinese way and keeps them from becoming too Western, Shylock does not have the same success. ${ }^{50} \mathrm{He}$ is unable to prevent Jessica from being swayed by the play's equivalent of a Western influence. ${ }^{51}$

Unlike Coriolanus, who values his mother's judgment about himself more than his own, Jessica does not internalise her father's view of her best interests. Further, unlike Coriolanus, Jessica does not feel indebted to her parent for the care he has given her. She sees her father as merely an obstacle to achieving her own goal of assimilation and acceptance among the Christians. And she sees his money as a means of attaining that goal. Jessica rebels against her father's imposition of austerity in their household. Speaking to their servant, Launcelot Gobbo, who has decided to leave Shylock's employ to go to work for the profligate Bassanio (and, of course, to be paid with money borrowed from Shylock), Jessica begins by saying: 'I am sorry thou wilt leave my father so.' 52 We soon realise, however, that it is not the humiliation of her father at having his servant quit him for a man who is her father's creditor, but rather her own loss that concerns her:

Our house is hell, and thou, a merry devil,

Didst rob it of some taste of tediousness. 53

The depth of Jessica's hatred of her father's vision of what is good for her goes beyond mere resentment. Jessica profoundly rejects her whole upbringing, her Jewishness, her father and her culture. She says:

Alack, what heinous sin is it in me

To be ashamed to be my father's child!

But though I am a daughter to his blood,

I am not to his manners. O Lorenzo,

If thou keep promise, I shall end this strife,

Become a Christian and thy loving wife. 54

She condemns herself for being ashamed of her father but forgives herself because of the profound difference she sees between herself and him. ${ }^{55}$ Daughter to Shylock's Jewish blood only, Jessica hopes her Christian manners will secure a saviour for her in the form of a Christian husband. But belying the naivety and vulnerability Shylock attributes to her, Jessica does not trust to her own charms to land Lorenzo. She knows she is stigmatised as a Jew and sets about making up for it; sweetening the deal by stealing her father's money. Jessica orchestrates her escape, making sure Lorenzo knows that she will be wellprovisioned with riches stolen from her father. ${ }^{56}$ Shylock knows nothing of his daughter's rebellion and is unaware of her complete rejection of his authority. As he unknowingly takes his final leave of her he says:

50 Chua (n 1) 5.

51 Ibid.

52 Merchant (n 11) II.iii.1, 139.

53 Ibid II.iii.2-3, 139.

54 Ibid II.iii.16-21, 139.

55 See Miller (n 11) 78, where he describes the theme of Merchant as not allowing like to produce like.

56 Lorenzo reports the contents of her letter to him: 'She hath directed/ How I shall take her from her father's house,/ What gold and jewels she is furnish'd with,/ What page's suit she hath in readiness' (II.iv.29-32, 141). 
Well, Jessica, go in;

Perhaps I will return immediately:

Do as I bid you; shut doors after you:

Fast bind, fast find;

A proverb never stale in thrifty mind. 57

Shylock speaks to his daughter as the static authority figure bidding her to shut herself up. Yet, ironically, the adage he closes with, spoken perhaps more to himself than to her, expresses a misplaced faith in an axiom that one can secure control over one's possessions and even one's children by locking them up. 'Fast bind, fast find', as though if you nail your possessions (including your children) down, they will be there when next you want them. Though he attempts to bind Jessica to their Jewish household and values, he walks out the door not knowing how profoundly he has failed in that attempt and that he has lost her forever.

\section{(B) SHYLOCK'S FAILURE AND HIS OWN RUIN}

Shylock fails to secure his daughter's consent to his authority because he omits key elements of the tiger-parent model. In the tiger-mother model consent is fixed through a powerful combination of three emotional factors. First the tiger parent engages in intense and intimate emotional manipulation of the child to get the child to internalise a sense of his or her obligation to obey the parent. This emotional manipulation is grounded in the rhetoric of the child's best interests, their guilty indebtedness and the parent's divine right. Second, the tiger parent seduces the child to a grandiose vision of his or her potential. Public glory is held out as the reward for obedience. And, third, the tiger parent's own vital attachment to vicarious pleasure in the child's achievements, their capacity and desire to live through the child, sets up a further emotional pull for the child in which the child comes to see the parent's experience and desire as of a higher order and therefore as carrying greater weight in their decision-making than their own.

Shylock misses the mark on all three accounts. First, Shylock is unaware that he needs Jessica's participation to create a structure of authority over her and, thus, he misjudges its foundation. Unlike Volumnia and Chua, he does not theorise his parental authority in an emotionally engaged way with his child. Shylock and Jessica do not fight and therefore they are not intimate. He does not know enough about her to perceive the need to manipulate her into accepting his authority, and she in turn gives him no opportunity to learn about her. Shylock assumes that telling her that she is bound to obey will be sufficient to secure her obedience. He underestimates the significance of her vulnerability, assuming that it translates into a dependence on him that will motivate her to accept his authority. But he does not engage with her in a way that would lead her to internalise a sense that as her father's debtor she owes him obedience.

Unlike Volumnia, Shylock does not dramatise himself as having given much to his child. And though, as a Jew alone in a hostile world trying to protect his daughter, he may have sacrificed far more for Jessica than Volumnia ever did for Coriolanus, he does not perceive the need to cast himself in that light such that his selflessness will become an emotional reality for her.

Of course, Jessica ultimately becomes a most guilty debtor of Shylock; robbing him, deserting him and eventually becoming the beneficiary of all his property. And her capacity for such total rebellion is nurtured by a dominant culture ruled by the principle that the 
Jew should never, no matter the evidence, be acknowledged as a legitimate creditor. Jessica can refuse her father the authority of a creditor because she lives in a world eager to back her up and to reread any violation of Shylock as justice and fair comeuppance. The ultimate tragedy of Shylock lies in his naïveté on this count. He miscalculates in all his relationships: with Jessica, Antonio and the law itself, because he does not realise that the obligations of indebtedness do not exist where he is acting as creditor. ${ }^{58}$ Perhaps no amount of emotional manipulation could have secured Jessica against the pull of the dominant culture's disbelief in the possibility of moral debt to Shylock. But the pathos of Shylock lies in his misplaced certainty that his status as his daughter's creditor would be enough to secure his authority over her.

Shylock's second mistake in applying the tiger-parent model is in his failure to engage Jessica's ego and ambition by selling her a seductive vision of herself. Like the dominant culture that surrounds her, Jessica values money, luxury and celebrity. She idolises the fair Portia's fame, wealth and beauty. ${ }^{59}$ But Shylock offers her no vision of the future except one of virtuous Jewish womanhood, which probably includes marriage to another pariah Jew. This reveals a key difference between Shylock as an outsider father and Chua's notion of the tiger mother. For Shylock, protecting his daughter from the influence of the dominant culture is a good in itself. He means to keep her away from it for good. For Chua, however, protecting the child from Western influence is instrumental to achieving fame and fortune on Western culture's terms. The point of the deprivation is to produce a child who can beat the Westerner kids at their own game. The tiger-mother model exploits a contradiction - Western culture loves money, fame and power - but it loves luxury, ease and self-satisfaction even more. Denying all the temptations of ease, the tiger mother gives her outsider child the rigorous training necessary to trounce the insiders in the race for glory. Despite her austerity she gives her minority child a dream of entering the dominant culture, not as a devalued other but as a star. One can hardly imagine a more potent motivation for the child to acquiesce in the authority of the parent. Shylock, by contrast, deprives his daughter of the indulgences of the dominant culture while offering nothing but a vision of continued isolation in a minority culture that values piety and religious observance over luxury and pleasure.

The final omission in Shylock's application of the tiger-mother model is the absence of any vicariousness in the relationship. Shylock does not live through Jessica; he gives no indication that the fulfilment of his wishes for her will bring him joy. Thus, unlike Coriolanus, Jessica is not motivated by the pleasure of giving her father vicarious satisfaction in fulfilling his ambitions for her. Coriolanus, dominated by the powerful and clear desires of his mother, is unable to validate and sometimes even to know his own desires. Coriolanus gives his mother's desires more weight than his own, because his own uncertain desires always lose against the absolute and obsessive certainty of Volumnia's wishes for him. But here again, Shylock misses the mark. By not giving Jessica the pleasure of pleasing him he misses out on another potential hold on her psyche that he might have used to secure her consent and prevent her rebellion.

58 Jessica seems to be aware, however, that her own Jewishness and perhaps her status as a woman do combine to erase her status as creditor to Lorenzo.

59 See the following exchange between Lorenzo and Jessica - Lorenzo: 'How dost thou like the Lord Bassanio's wife?'; Jessica: 'Past all expressing. It is very meet/ The Lord Bassanio live an upright life;/ For, having such a blessing in his lady,/ He finds the joys of heaven here on earth;/ And if on earth he do not mean it, then/ In reason he should never come to heaven/ Why, if two gods should play some heavenly match/ And on the wager lay two earthly women,/ And Portia one, there must be something else/ Pawn'd with the other, for the poor rude world/ Hath not her fellow' (III.v.67-77, 186-87). 


\section{Conclusion}

There is a strain of self-irony in Chua that is largely ignored in the commentary and discussion of her ideas. Her frequent descriptions of her husband Jed's ridicule of her provide not just comic but real relief from her relentless drilling. She doesn't hesitate to drop in a self-deprecating line, poking fun, for example, at her intellectual ambitions for her Samoyed dogs. In the end, Chua admits some reservations about her model of mothering. She recognises that, by trying to completely control her younger and more rebellious younger daughter Lulu, she risked complete alienation from her. ${ }^{60}$ Ultimately, Chua concedes that losing her daughter would be worse than losing absolute control over her daughter. Though that call would be obvious and immediate for most parents, we still credit Chua with a moral breakthrough for getting there.

At the end of the book Chua considers a compromise: 'The Chinese way until the child is eighteen, to develop confidence and the value of excellence, the Western way after that. Every individual has to find their own path. ${ }^{61}$ What Shakespeare's depiction of Coriolanus shows is that going from submission to tyrannical authority as a child to effective self-rule in adulthood may be impossible. Children habituated to valuing their parent's external preferences over their own internal ones may not have the capacity to know let alone honour their own truth. Likewise, Merchant of Venice shows us that, unless the tiger parent successfully seduces the child with dreams of glory, the child may refuse to participate at all in the construction of the parent's authority. The plays depict the potential pathologies of the tiger-mothering model and serve as cautionary tales. 
